\title{
Assay of human plasma cortisone by liquid chromatography: normal plasma concentrations (between 8 and 10 a.m.) of cortisone and corticosterone
}

\author{
M. Hariharan*, Sundar Naga, Ted VanNoord and Erick K. Kindt \\ Department of Psychiatry, University of Michigan Medical School, 1150 W. Medical Center Drive, Ann Arbor, MI 48I09-0656 \\ $(U S A)$
}

(First received September 15th, 1992; revised manuscript received December 7th, 1992)

\section{ABSTRACT}

\begin{abstract}
A high-performance liquid chromatographic method using ultraviolet detection to quantitate human plasma concentrations of cortisone simultaneously with cortisol and corticosterone is described. The method is based on the use of an octadecyl silica column $(100 \mathrm{~mm} \times 2 \mathrm{~mm}$ I.D., $3 \mu \mathrm{m})$, an ultraviolet absorbance detector $(242 \mathrm{~nm})$ with a $10 \mathrm{~mm}$ path length flow-cell, and a mobile phase composed of water-tetrahydrofuran-acetonitrile $(82: 10: 8, \mathrm{v} / \mathrm{v})$ containing $5 \mathrm{ml} / 1$ triethylamine and citric acid to adjust the $\mathrm{pH}$ of the buffer to 6.5. Flumethasone is used as the internal standard. The detection limit of the method for the three steroids is $300 \mathrm{ng} / \mathrm{l}$ using a $1-\mathrm{ml}$ sample. The average inter-assay coefficient of variation for cortisone is $3.3 \%$ and the average recovery is $100.8 \%$. Possible interferences from common drugs and endogenous and exogenous steroids in the method have been studied. Plasma concentrations (drawn from 8 to 10 a.m.) of cortisone and corticosterone for 43 normal volunteers have been determined.
\end{abstract}

\section{INTRODUCTION}

Cortisone (E) is a physiologically inactive steroid formed by the oxidation of cortisol $(\mathrm{F})$ by the enzyme $11 \beta$-hydroxysteroid-dehydrogenase $(11 \beta$ $\mathrm{OHSDH}$ ) present in various tissues. It is reduced back into active cortisol, and an equilibrium $\mathrm{E} \leftrightarrow \mathrm{F}$ exists in many human tissues such as liver, kidney, adipose, brain, lung, testis, uterus, placenta, and parotid gland [1-3]. Human pharmacokinetics [4] and metabolism of $F$ and $E$, their interconversions and equilibria in different pathologic conditions [5-7], and the dual nature (oxoreductase and dehydrogenase) of $11 \beta$-OHSDH $[3,8]$ have all been studied quite extensively.

$F$ and $E$ are usually quantitated by independent methods only. In the early days $F$ was analyzed

\footnotetext{
* Corresponding author.
}

after initial extraction from plasma and purification by Scphadex LH-20 column chromatography, followed by competitive protein binding assay [9]. In 1973 Srivastava et al. [10] introduced a radioimmunoassay (RIA) for $E$. This method is the only available choice for human plasma and saliva and it requires initial extraction and purification by thin-layer or high-performance liquid chromatography (HPLC) [11]. Human urine contains fairly high concentrations of free $\mathrm{E}(54 \pm$ $50 \mu \mathrm{g}$ per $24 \mathrm{~h})$ and $\mathrm{F}(22 \pm 18 \mu \mathrm{g}$ per $24 \mathrm{~h})$ and both steroids have been simultaneously, accurately, and precisely measured by HPLC-UV [12]. Total human plasma and urine E concentrations can also be estimated by gas chromatography after enzymatic hydrolysis, extraction, purification, and derivatization [13]. Although HPLC is a readily available, powerful, and simple tool requiring no prior derivatization, very little is 
known about its use for determining the low levels $(<30 \mu \mathrm{g} / \mathrm{l})$ of free human plasma $\mathrm{E}$ concentrations. However, Wade and Haegele [14] published a HPLC-UV method for human saliva $E$ and $F$ assays. It has many weak features: the HPLC system is unnecessarily sophisticated, the analytical column is too long $(250 \mathrm{~mm} \times 2 \mathrm{~mm}$ I.D. $)$, the nature of mobile phase mandates column thermostating at $50^{\circ} \mathrm{C}$, and the extraction is cumbersome, involves deproteinization of saliva, and requires up to $6 \mathrm{ml}$ of sample.

We recently developed a simple, sensitive (detection limit of $300 \mathrm{ng} / \mathrm{l}$ using $1 \mathrm{ml}$ of plasma), and highly reproducible HPLC--UV method that distinctly separated E, F, 11-deoxycortisol (S), corticosterone (B), deoxycorticosterone (DOC), dexamethasone (D), 17-hydroxyprogesterone (17$\mathrm{OHP}$ ), and progesterone $(\mathrm{P})$ [15]. In this paper we describe a sensitive, specific analysis of human plasma E by reversed-phase HPLC and provide comprehensive precision, accuracy, recovery, and linearity data for the method. We have also determined plasma concentrations (drawn from 8 to 10 a.m.) of $B$ and $E$ in 43 normal volunteers.

\section{EXPERIMENTAL}

\section{Reagents and materials}

Cortisol $(98.9 \%)$ was obtained from the $\mathrm{Na}$ tional Institute of Standards and Technology (Gaithersburg, MD, USA), and cortisone (98\%) from Sigma (St. Louis, MO, USA). Flumethasone and corticosterone were from Steraloids (Wilton, NH, USA). HPLC-grade acetonitrile (ACN), methanol, and tetrahydrofuran (THF), were from Burdick \& Jackson (Muskegon, MI, USA). Reagent-grade triethylamine and citric acid were from Fisher Scientific (Fair Lawn, NJ, USA). Steroid-stripped plasma was from Biocell (Carson, CA, USA). The all-PTFE $\mathrm{C}_{18}$ solid-phase extraction (SPE) columns (Tef Elutor), $2 \mathrm{ml}$ capacity and containing $200 \mathrm{mg}$ of material, were obtained from Versa Prep Lab Systems (Nanuet, NY, USA). SPE was carried out with Baker SPE systems (J. T. Baker, Phillipsburg, NJ, USA). The 10-ml all-PTFE tubes (Oak Ridge type from Nalgene) used throughout the extraction work were from VWR Scientific (Chicago, IL, USA). (Note: PTFE tubes are not essential for the extraction work.)

\section{Instrument and mobile phase}

The HPLC unit consisted of a Model L-6000 pump (Hitachi, Tokyo, Japan), a Model 710B WISP autosampler (Waters, Milford, MA, USA), an octadecyl silica (ODS) 3- $\mu$ m Shandon Hypersil column (100 mm $\times 2 \mathrm{~mm}$ I.D.) (Keystone Scientific, Bellefonte, PA, USA), a Model 480 ultraviolet detector (Waters) with a $10 \mathrm{~mm}$ path length flow-cell set at $242 \mathrm{~nm}$, and a Model D-2000 integrator-plotter (Hitachi). The mobile phase was a mixture of water-THF-ACN $(82: 10: 8, \mathrm{v} / \mathrm{v})$, containing $5 \mathrm{ml} / 1$ triethylamine and citric acid to adjust the $\mathrm{pH}$ to 6.5 . The flow-rate was $0.6 \mathrm{ml} /$ $\min$.

\section{Standard solutions}

A $250-\mathrm{ml}$ aliquot of a primary stock solution was prepared by dissolving $25 \mathrm{mg}$ of cortisone in methanol. Working standard solutions were prepared in either steroid-stripped serum or methanolic saline $(20 \mathrm{ml}$ of methanol and $8 \mathrm{~g}$ of sodium chloride per liter) and contained 1, 4, 10, 20, 40, 80 , and $200 \mu \mathrm{g} / 1$ cortisone. The aqueous and serum-based standards were used in no set order. In all cases, serial standardizations were performed. The working internal standard solution contained $20 \mathrm{ng}$ of flumethasone per $50 \mu \mathrm{l}$ of solution.

\section{Extraction}

The extraction procedure for all the samples using Tef Elutor SPE $\mathrm{C}_{18}$ columns is described elsewhere [15]. The final nitrogen gas-evaporated residue was reconstituted in $50 \mu$ of mobile phase, and $25 \mu \mathrm{l}$ of the solution were injected into the HPLC system using an autosampler.

\section{RESULTS AND DISCUSSION}

\section{Calibration}

A scries of standards covering the range 0 $200 \mu \mathrm{g} / 1$ were used in daily work. The regression line between the ratio of peak heights (component 
peak height/internal standard peak height) and the concentration of cortisol was calculated and used for determining the unknowns. A typical regression line was $y=0.0009+0.2840 x\left(r^{2}=\right.$ 0.9997).

\section{Linearity}

Steroid-stripped plasma samples were spiked with cortisone in the concentration range 0 $200 \mu \mathrm{g} / 1$ and analyzed several times ( $n>20$ ), and the absorbances of the standards were linear throughout the range.

\section{Precision}

Inter-assay and intra-assay coefficients of variation (C.V.) were determined using three plasma pools on the range $4.5-30 \mu \mathrm{g} / 1$ (covering the normal human range). The data are presented in Table I. The average inter-assay C.V. for E was $3.3 \%$.

\section{Accuracy}

E was added to steroid-stripped plasma in the concentration range $(2-200 \mu \mathrm{g} / \mathrm{l})$ we encountered in our work. We determined both inter-assay and intra-assay recoveries for these samples by the method (Table II). The average inter-assay recovery was $100.8 \%$.

\section{Limit of detection}

The detection limit of the assay was $300 \mathrm{ng} / \mathrm{l}$

\section{TABLE I}

PRECISION DATA FOR HUMAN PLASMA CORTISONE $\operatorname{ASSAY}(n=8)$

\begin{tabular}{ll}
\hline Concentration & C.V. \\
$($ mean + S.D. $)(\mu \mathrm{g} / \mathrm{ml})$ & $(\%)$ \\
\hline
\end{tabular}

\begin{tabular}{cc}
\hline Inter-assay & \\
$4.88 \pm 0.19$ & 3.9 \\
$15.99 \pm 0.50$ & 3.1 \\
$29.87 \pm 0.87$ & 2.9 \\
Intra-assay & \\
$4.76 \pm 0.12$ & 2.5 \\
$15.64 \pm 0.45$ & 2.9 \\
$29.15 \pm 0.61$ & 2.1 \\
\hline
\end{tabular}

TABLE II

RECOVERY DATA FOR CORTISONE IN STEROIDSTRIPPED PLASMA

\begin{tabular}{lrr}
\hline $\begin{array}{l}\text { Spiked } \\
(\mu \mathrm{g} / \mathrm{l})\end{array}$ & $\begin{array}{l}\text { Measured } \\
(\text { mean } \pm \mathrm{S} . \mathrm{D} .)(\mu \mathrm{g} / \mathrm{l})\end{array}$ & $\begin{array}{l}\text { Recovery } \\
(\%)\end{array}$ \\
\hline $\begin{array}{l}\text { Inter-assay }(n-8) \\
2.0\end{array}$ & $2.1 \pm 0.1$ & 105.0 \\
8.0 & $8.1 \pm 0.2$ & 101.3 \\
20.0 & $19.8 \pm 1.2$ & 99.0 \\
40.0 & $40.2 \pm 1.5$ & 100.5 \\
80.0 & $79.6+2.8$ & 99.5 \\
200.0 & $198.7 \pm 5.3$ & 99.4 \\
Intra-assay $(n=6)$ & & \\
2.0 & $2.1 \pm 0.1$ & 105.0 \\
20.0 & $20.1 \pm 1.0$ & 100.5 \\
80.0 & $80.2 \pm 2.2$ & 100.3 \\
200.0 & $199.2 \pm 4.7$ & 99.6 \\
\hline
\end{tabular}

using $1 \mathrm{ml}$ of sample, at a signal to noise ratio of $3: 1$. This detection limit is lower than the normal values observed in human populations.

\section{Selectivity}

The assay was reasonably more specific than the RIA method [10]. We determined the retention times of many endogenous and exogenous steroids and commonly used drugs [15].

Earlier HPLC methods for quantitating glucocorticoids in human plasma [16-22] had the following drawbacks. (1) Most of the analytical columns were long ( $\geq 250 \mathrm{~cm}$ ) and contained 5 - or $10-\mu \mathrm{m}$ packing materials which were responsible for poor resolutions and increased assay times [16-22]. (2) Analytical columns were thermostated for improving the resolution and decreasing the assay time per sample $[16,17,19,20]$. (3) Earlier mobile phase compositions were not conducive for good resolution and short assay time [16-22]. (Note: progesterone is generally coextracted with the glucocorticoids and elutes very late in the reversed-phase method.) (4) It is not clear if the earlier workers [ [l 16 22] took advantage of the possible higher sensitivities in the assay by using a minibore column and longer path length 
flow-cell as shown by Taylor et al. [23]. One of the most successful mobile phase compositions for the separation of glucocorticoids contains $\mathrm{THF}$ [20], a solvent of intermediate eluotropic behavior between methanol (low) and ACN (high). Greater flexibility of mobile phase optimization results when a binary mixture of THF and ACN is chosen. Dawson et al. [20] using a mobile phase of THF-ACN-water $(12: 10.5: 77.5, \mathrm{v} / \mathrm{v})$ and a $\mathrm{C}_{8}$ column $(5 \mu \mathrm{m}, 250 \mathrm{~mm} \times 4.5 \mathrm{~mm}$ I.D. $)$ at $50^{\circ} \mathrm{C}$ resolved $E, F, B, D$, etc. very nicely. However, their detection limit was $\geq 15 \mu \mathrm{g} / \mathrm{l}$. We modified the method of Dawson et al. [20] using a minibore ODS column (100 $\mathrm{mm} \times 2 \mathrm{~mm}$ I.D., $3 \mu \mathrm{m}$, theoretical plate count of $c a .8000$ ) and a detector with a $10-\mathrm{mm}$ path length flow-cell. We also improved upon earlier SPE methods by ensuring $>90 \%$ extraction efficiencies [15], and optimized the composition of the mobile phase of THF ACN-citrate buffer $(10: 8: 82$, v/v) for a good isocratic resolution at ambient temperature of many endogenous and exogenous steroids. The cumulative effects of our modifications of the method resulted in a detection limit of $300 \mathrm{ng} / \mathrm{l}$ for the glucocorticoids E, F, and B [15]. Slight modifications of the mobile phase would enable the separation of any combination of synthetic and endogenous steroids. We investigated the possibility of using still shorter columns (75 or $50 \mathrm{~mm} \times 2 \mathrm{~mm} \mathrm{I.D.)}$ in the hope of reducing the analysis time per sample, but found that the optimal mobile phase composition that would
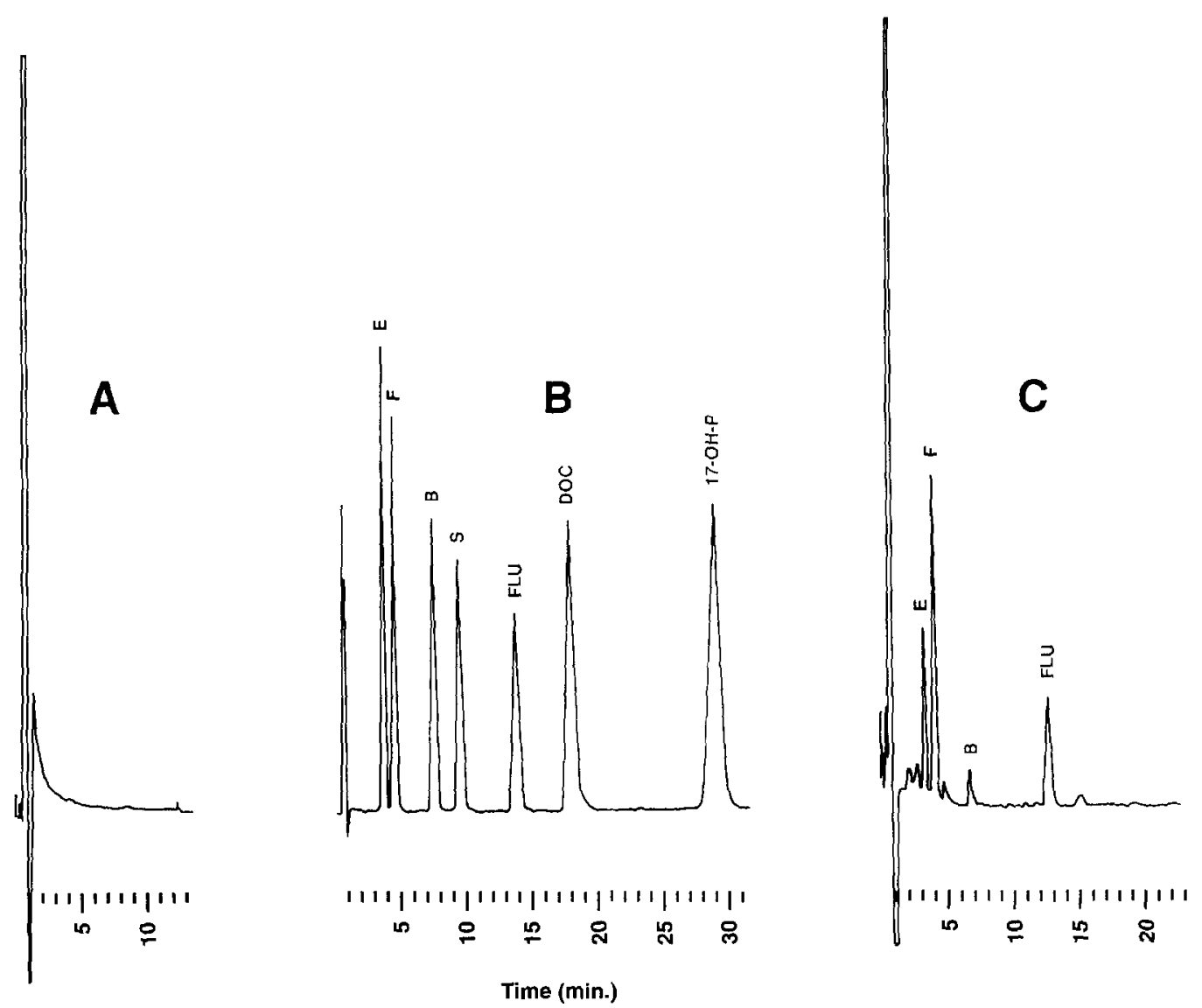

Fig. 1. Representative liquid chromatograms of (A) reagent water blank, (B) 25 ng each of E, F, B, S, flumethasone (FLU) and 50 ng each of DOC and $17-\mathrm{OHP}$ and $(\mathrm{C}) \mathrm{l}-\mathrm{ml}$ plasma extract containing $12.2 \mu \mathrm{g} / \mathrm{L}, 23.76 \mu \mathrm{g} / \mathrm{F}$, $3.1 \mu \mathrm{g} / \mathrm{l} \mathrm{B}$, and $20 \mu \mathrm{g} / \mathrm{l} \mathrm{FLU}$ (internal standard). Refer text for other abbreviations. Integrator attenuation is $2^{3}$. 
resolve the different glucocorticoids will preclude it. However, the assay time per sample can be reduced to less than $20 \mathrm{~min}$ if progesterone (especially in female patient samples) is removed by including a wash step of methylene chloride and hexane $(5: 95, v / v)$ either at the beginning of the extraction or just prior to elution at the end with methanol in the SPE [15].

Fig. 1 shows representative chromatograms obtained in this work. The peaks are sharp and baseline-resolved. The assay time per sample is $c a$. $20 \mathrm{~min}$. The present work, in conjunction with our earlier paper [15] for the simultaneous analysis of $\mathrm{F}$ and $\mathrm{B}$, would form a good and comprehensive HPLC-UV method for the three most relatively abundant glucocorticoids (E, F, and B) in human plasma.

Cortisone is a pharmacologically inactive steroid (the 11-OH group is essential for activity) but the equilibrium $\mathrm{E} \leftrightarrow \mathrm{F}$ lies predominantly towards the right (reduction) in the liver. Liver is the largest site for the reduction of cortisone, and the magnitude of this reduction is greater than the magnitude of oxidation in kidney or testis [3]. In cirrhosis the equilibrium in the liver is maintained but the half-life of $\mathrm{F}$ is increased from $c a .1 .0 \mathrm{~h}$ to $5 \mathrm{~h}$ [24]. The kidney, parotid gland, placenta, and testis are major sites where $F$ is oxidized predominantly to $\mathrm{E}[1,25]$. Among the oxidative tissues kidney ranks highest and testis second [25]. It has been shown that the renal $11 \beta$-OHSDH protects the kidney from the mineral corticoid actions of $F$ $[25,26]$. In kidney failure, the plasma level of $E$ is much lower than in normal controls [27]. Hyperthyroid individuals convert $\mathrm{F}$ more readily to $\mathrm{E}[6]$ and the opposite is true in hypothyroidism and inflammatory diseases $[5,6]$. In pregnancy and during oral contraceptive use the total concentrations of $\mathrm{F}$ and $\mathrm{E}$ are higher than normal but the concentrations of the free compounds change little. Thus, the disposition of $\mathrm{E} \leftrightarrow \mathrm{F}$ equilibrium is different in different tissues and it can vary depending upon its pathological status $[5,6,24,27]$ and the drugs the person is using [28]. According

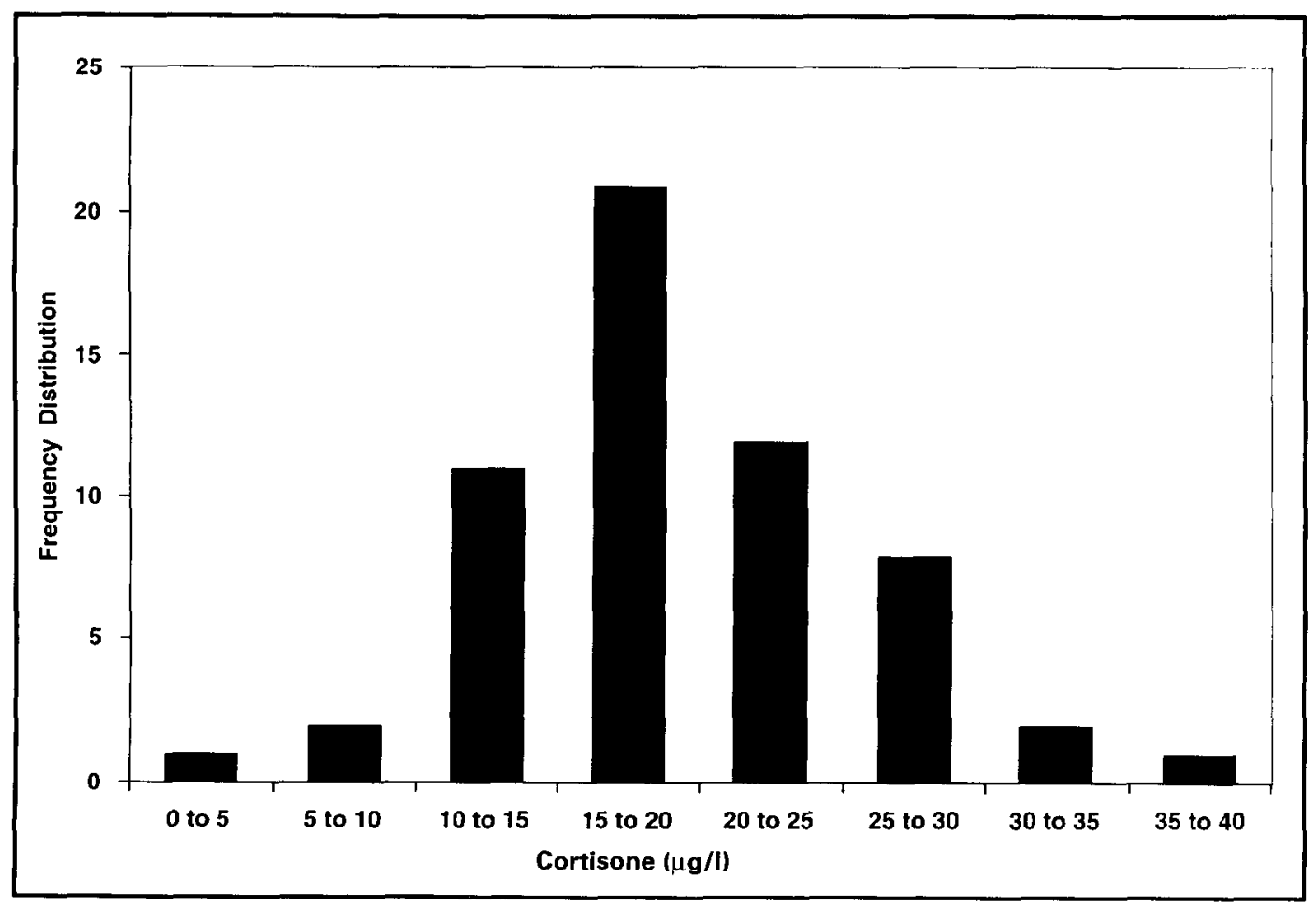

Fig. 2. Histogram of human plasma cortisone of 43 normal volunteers (drawn between 8 and 10 a.m.). 
to Monder [25] the selectivity, specificity, and extent of glucocorticoid responses in tissues is modulated by the reversible function of the enzyme $11 \beta$-OHSDH and the time variable needs of the tissue.

In the light of all the facts on the $\mathrm{E} \leftrightarrow \mathrm{F}$ equilibrium and the enzyme $11 \beta$-OHSDH, it seems that a better way to monitor the glucocorticoid activity would be to determine simultaneously, by this HPLC-UV method, the concentrations of the three relatively abundant compounds $\mathrm{E}, \mathrm{F}$, and $\mathrm{B}$ rather than the most abundant F alone by RIA. From our limited study we find that the plasma concentration of $\mathrm{E}$ is about $25 \%$ of the concentration of $F$ while that of $B$ is about $5-10 \%$. Thus a possible additional $30-35 \%$ glucocorticoid activity would be of much significance. Lewbart and Elverson [12] suggested that the urinary free E concentration cannot be ignored because of its variable interconversion with cortisol in vivo.

\section{Normal values}

Cortisone. The values for 43 normal volunteers (aged 20-70 years; drawn between 8 and 10 a.m.; non-fasting) are plotted as a histogram (Fig. 2). The histogram shows a Gaussian distribution. The concentration (mean $₫$ S.D.) of the sample is $19.36 \pm 6.6 \mu \mathrm{g} / 1$ (drawn between 8 and 10 a.m.). This value compares quite favorably with those reported by Sippell et al. [29] and determined by RIA following Sephadex column chromatography $(17.3 \pm 3.1 \mu \mathrm{g} / \mathrm{l}$ for 12 males; $13.5 \pm 2.9$ for 12 females; samples drawn between 9 and 10 a.m.).

Corticosterone. The values for the 43 samples determined by this HPLC method do not fall into a Gaussian distribution pattern (Fig. 3). We calculated the concentrations (mean \pm S.D.) using statistical methods to be $1.78 \pm 0.60 \mu \mathrm{g} / \mathrm{l}$. The values are lower than those in earlier reports [29] perhaps due to the higher proportion of males ( $c a$. $85 \%$ ), the wider range of the age of our volunteers. the slightly different blood drawing times

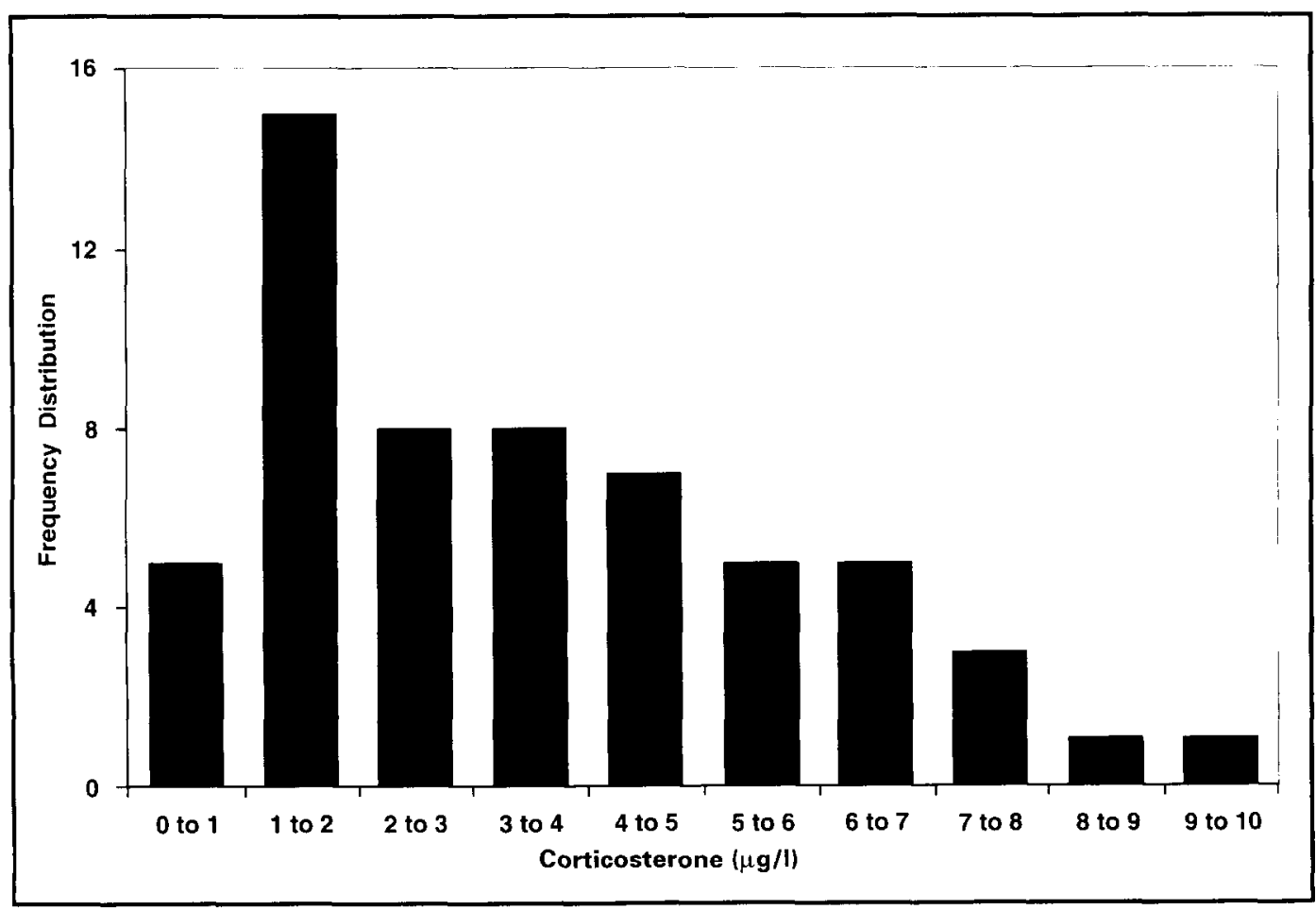

Fig. 3. Histogram of human plasma corticosterone of 43 normal volunteers (drawn between 8 and 10 a.m.). 
(8-10 a.m.) and the larger population size of our samples compared to earlier methods.

\section{CONCLUSION}

The outlined reversed-phase ambient-temperature HPLC method is simple, sensitive, specific, accurate, and precise and a viable alternative to the present and only RIA method for human plasma E measurement. The method is economical since it cuts down the amount of the mobile phase used (flow-rate of $0.6 \mathrm{ml} / \mathrm{min}$ ) and the assay time per sample (compared to earlier methods [16-22]). The big advantage of this HPLC method is that one can simultaneously measure many endogenous and exogenous steroids. An endogenous steroid profilc consisting of $\mathrm{E}, \mathrm{F}, \mathrm{B}, \mathrm{S}$, DOC, 17-OHP, and $\mathrm{P}$ is quite useful in a detailed study of different types of adrenal hyperplasia as shown by Ji-qing et al. [30]. Also a knowledge of the plasma concentrations of the glucocorticoids (E, F, and B) instead of just the F level could be more informative in investigating the pathological conditions of different organs (liver, kidney, adrenal, and thyroid gland), inflammatory diseases and hypothalmic-pituitary-adrenal axis dysfunctions.

\section{REFERENCES}

1 B. E. P. Murphy, J. Steroid Biochem., 14 (1981) 811.

2 J.A. Whitworth, P. M. Stewart, D. Burt, S. M. Atherden and C. R. W. Edward, Clin. Endocrinol., 31 (1989) 355.

3 C. Monder, FASEB J., 5 (1991) 3047.

4 E. J. Begg, II. C. Atkinson and N. Gianarakis, Med. J. Aust., 146 (1987) 37

5 Y. Ichikawa, K. Yoshida, M. Kawagoe, E. Saito, Y. Abe, K. Arikawa and M. Homma, Metabolism, 26 (1977) 989.

6 B. Zumoff, H. L. Bradlow, J. Levin and D. K. Fukushima, J. Sternid Biochem., 18 (1983) 437.

7 M. Abramovitz, C. L. Branchaud and B. E. P. Murphy, J. Clin. Endocrinol. Metab., 54 (1982) 563.
8 C. Monder and C. H. L. Shackleton, Steroids, 44 (1984) 383.

9 B. E. P. Murphy, J. Clin. Endocrinol. Metab., 27 (1967) 973.

10 L. S. Srivastava, E. E. Werk, K. Thrasher, L. J. Sholiton, R. Kozera, W. Nolten and H. C. Knowles, J. Clin. Endocrinol. Metab., 36 (1973) 937.

11 P. M. M. Meulenberg, H. A. Ross, L. M. J. W. Swinkelees and T. J. Benraad, Clin. Chim. Acta, 165 (1987) 379.

12 M. L. Lewbart and R. A. Elverson, J. Steroid Biochem., 17 (1982) 185.

13 C. W. Weykamp, T. J. Penders, N. A. Schmidt, A. J. Borburgh, J. F. Van de Calseyde and B. J. Wolthers, Clin. Chem., 35 (1989) 2281.

14 S. E. Wade and A. D. Haegele, J. Liq. Chromatogr., 18 (1981) 1813.

15 M. Hariharan, S. Naga, T. VanNoord and E. K. Kindt, Clin. Chem., 38 (1992) 336.

16 P. M. Kabra, L. L. Tsai and L. J. Morton, Clin. Chem., 125 (1979) 1293.

17 E. Canalis, G. E. Reardon and A. M. Calderella, Clin. Chem., 28 (1982) 2418.

18 W. E. Lambert, J. M. De Slypere, J. A. Jonckheere, A. Vermeulen and A. P. De Leenheer, Anal. Biochem., 134 (1989) 216.

19 G. R. Gotelli, J. H. Wall, P. M. Kabra and L. J. Marton, Clin. Chem., 27 (1981) 441.

20 R. Dawson, P. Kontur and A. Monjan, Horm. Res., 20 (1984) 89.

21 K. Oka, M. Noguchi, T. Katamura and S. Shima, Clin. Chem., 33 (1987) 1639.

22 D. C. Turnell, J. D. H. Cooper, B. Green, G. Hughes and D. J. Wright, Clin. Chem., 34 (1988) 1816.

23 R. B. Taylor, K. E. Kendle and R. G. Reid, J. Chromatogr., 385 (1987) 383.

24 R. E. Peterson, Ann. N.Y. Acad. Sci., 82 (1959) 846.

25 C. Monder, Ann. N.Y. Acad. Sci.. 595 (1990) 26.

26 S. Ulick, L. S. Levine, P. Gunczler, G. L. C. Ramirez, W. Rauth, A. Rosler, H. L. Bradlow and M. I. New, J. Clin. Endocrinol. Metab., 49 (1979) 757.

27 A. Kowarski, B. Lawrence, W. Hung and C. J. Migeon, J. Clin. Endocrinol., 29 (1969) 377.

28 Y. Choi, K. Thrasher and E. E. Werk, J. Pharmacol. Exp. Ther., 176 (197I) 27.

29 W. G. Sippell, F. Bidlingmaier, H. Becker, T. Brunig, H. Dorr, H. Hahn, W. Golder, G. Hollmann and D. Knoor, J. Steroid Biochem., 9 (1968) 63.

30 W. Ji-qing. Z. Xian-teng and W. Ji-lu, Clin. Chem., 33 (1987) 1354. 